\title{
ACADEMIC LITERACY AND GENRES IN UNIVERSITY LEARNING COMMUNITIES
}

\author{
Juana Marinkovich* \\ Pontificia Universidad Católica de Valparaíso \\ Valparaíso, CL \\ Marisol Velásquez ${ }^{* *}$ \\ Pontificia Universidad Católica de Valparaíso \\ Valparaíso, CL \\ Alejandro Córdova ${ }^{* * *}$ \\ Pontificia Universidad Católica de Valparaíso \\ Valparaíso, CL \\ Carolina Cid ${ }^{* * * *}$ \\ Pontificia Universidad Católica de Valparaíso \\ Valparaíso, CL
}

\begin{abstract}
The study of genre through different perspectives has contributed to a better understanding of how writing performs a major role in the enculturation process students must undergo when entering the university context. Considering that written genres instantiate the specific practices of disciplines, their different ways of doing and knowing (Carter, 2007), this study aims, by means of a qualitative approach, at exploring the way literacy in academic writing is addressed, according to the discourse of teachers and students of five different disciplinary communities at a Chilean university, based on the approach to their particular genres. The results reveal that, in the communities addressed, literacy in academic writing is conceived under two distinctive orientations: a formative and a prescriptive one, each of them associated to genres displaying expert and instructional characteristics, respectively.
\end{abstract}

Keywords: Academic Literacy; Academic Writing; Disciplinary Communities; Genres; Social Representations.

\footnotetext{
${ }^{*}$ Professor of the Institute of Literature and Language at the Pontifical Catholic University of Valparaiso, Chile. Ph.D. in Philosophy with emphasis in Hispanic Linguistics (University of Chile). Master in Translation (University of Montreal). Her research interests are literacy in academic writing both in Sciences and Humanities in Chilean universities, especially at the undergraduate level. Her email address is juana.marinkovich@pucv.cl

${ }^{* *}$ Professor at the Institute of Literature and Language Sciences of the Pontifical Catholic University of Valparaiso, Chile. She holds a BA in Hispanic Language and Literature and an MA in Applied Linguistics, both degrees from the Catholic University of Valparaiso (Chile). She has worked in the areas of teacher training, continuing education and initial training of teachers and has taught courses designed to develop reading and writing skills in college students from the areas of Education, Engineering and Law. Her email address is marisol.velasquez@pucv.cl

${ }^{* * *}$ Professor at School of Law of the Pontifical Catholic University of Valparaiso and at DuocUC, Viña del Mar. Bachelor of Hispanic Language and Literature at the Pontifical Catholic University of Valparaiso and Master in Social Communication with a minor in Communication and Education at the Pontifical Catholic University of Chile. He has worked in research projects focused on Academic Literacy. His research interests are related to academic, media and digital literacy. His email address is alejandro.cordova@pucv.cl

${ }^{* * * *}$ English as a Foreign Language teacher and Master of Applied Linguistics. She has been part of the technical staff of two Fondecyt projects that focus on the process of literacy in academic writing in undergraduate programs at Pontifical Catholic University of Valparaiso, Chile. Her email address is carolina.cid.f@ gmail.com
} 


\section{Introduction}

The interest in academic literacy, and, more specifically, writing in the disciplines in university contexts has been the focus of numerous investigations for many years from different perspectives and fields of studies (Carlino, 2003, 2006, 2013; Russell, 1990, 1991; Parodi, Ibañez \& Venegas, 2009). This interest originates from the recognition that initial literacy acquired during elementary and secondary education is not enough, as it does not allow for students to deal successfully with the demands of a given field of knowledge (Vásquez, 2005).When entering the university context, students encounter specialized knowledge, and therefore, need to develop specific strategies to participate in the different activities of text analysis and production required to learn in the higher education context (Carlino, 2003).

The study of genre through different perspectives (Hyon, 1996; Swales, 1990; Bazerman, 1988, 1994; Russell, 1997a) has contributed to a better understanding of how writing performs a major role in the enculturation process students must undergo once they take the university path. Considering that written genres instantiate the specific practices of disciplines, their different ways of doing and knowing (Carter, 2007), literacy in academic writing requires students to be competent writers of the different genres produced. In fact, from the Activity Theory perspective, genres are the tools that mediate the different activities performed in a given context, (Russell, 1997b), and students learn how to use these tools through the interaction with expert members of their communities.

Currently, academic literacy pedagogy emphasizes the role of teachers and educational institutions in the process of enculturation. This pedagogy attempts to engage students in their literate practices through teachers' actions and institutional support (Carlino, 2013; Wolfe, Olson \& Wilder, 2014). More specifically, the role of the disciplinary specialist becomes paramount when it comes to guide students in their enculturation process, as the heterogenous nature of academic writing may present a great hindrance to students. However, little attention has been paid to the influential role specialists may come to play. Thus, exploring the teacher's conceptions about literacy in academic writing, together with the students' own vision on this matter, will help us understand how this process is carried out in a given disciplinary community.

Therefore, this study ${ }^{1}$ poses the following questions: How is literacy in academic writing addressed, according to the discourse of teachers and students, literacy in academic writing based on the approach to the genres circulating in the disciplinary communities of Art, Biochemistry, Biology, History and Mathematics at a Chilean university? How is literacy in academic writing conceived within the disciplinary communities? Which academic genres are recognized in each of the disciplinary communities? How are these academic genres described?

Answering these questions can improve understanding of the way the members of these communities addressed foster, consciously or not, the acquisition of the different genres that circulate in them. Exploring how students acquire these genres adds to our view of the students' academic literacy process.

\section{Academic literacy and writing}

The study of academic literacy, focused primarily on writing as an epistemic tool for approaching, processing, communicating and learning disciplinary knowledge, first developed in the English-speaking world. Its history goes back to Writing Across the Curriculum (WAC) and Writing in the Disciplines (WID) movements in the last century. While the former conceives writing as part of first year general courses at American universities and gradually transformed into courses for different disciplines, the latter intends to investigate and delve into the characteristics of the texts of each discipline, as well as writing practices and associated genres.

The WID proposal orientation is reflected in two major lines of still existing research: a) one that studies the texts and discourses of professional representatives of a particular discipline, and b) one that studies texts written in the university disciplinary classrooms when it comes to learn that discipline (Russell, 1991; Camps \& Castelló, 2013). The new focus of the WID entailed 
important consequences, many of which have shaped the field of research into what is known now as academic writing by considering it as a culturally situated, social activity that conveys disciplinary contributions differentially; writing is an important tool to learn the contents and ways of thinking of these disciplines. The shift in focus also had a significant impact on educational proposals that, in general, assumed the need to focus attention beyond the stage of accessing higher education, understanding that as disciplinary content becomes more demanding and complex, writing practices also become more specific and, consequently, require explicit teaching if the purpose is to help students understand and use efficiently the contents and disciplinary discourse.

A third movement called Academic Literacies, which originated in the UK, also considers reading and writing practices as socially situated practices, especially, with a focus on the power relations that are shaped within those practices. In this regard, Lea and Street $(1998,2000,2006)$ propose three explanatory models to approach academic literacy. The first, called study skills, focuses on cognitive-linguistic skills, including writing related to general content that students may transfer to other contexts; the second, academic socialization, emphasizes activities that encourage acculturation, that is, those that will help students become familiar with the disciplinary community they will be part of, where they are expected to use the genres and discourses of their discipline effectively; and the third one, Academic Literacies, fosters social practices where reading and writing have an epistemic function and contribute to the construction of identity within the context of higher education. It incorporates academic socialization and, as a situated literacy process, demands particular learning strategies that are not usually acquired naturally, but must be taught.

\section{Academic community}

Academicliteracy is closelylinked to the community of teachers and students in higher education. Students gradually become members of an academic community through the genres and exposure to the methodologies of the disciplines, as well as through personal contact with teachers and other sectors of the university.

In addition, academic community is associated with the notion of community of practice (Wenger, 1998), and discourse community (Swales, 1990), although these notions differ in some aspects. While communities of practice, related to Lave and Wenger's idea of situated learning (1991), are groups of people who share a concern, a set of problems or interest in a subject, and generally share information, ideas and tips, helping each other to solve problems, discourse communities do not necessarily share common spaces, and their members may not even get to know each other.

Carlino (2006), extending to some extent Swales's ideas (1990), notes that discourse communities are constituted by a group of people who share knowledge and values and that both reading and writing have goals that these communities determine. In this regard, Silver (2006: 38) recognizes that these members also share the ideology, styles, among others and discursive characteristics: "we may define discourse community as people working within a particular area of knowledge with a shared repertoire of ideas and resources, who manifest their sense of community through the lexis, styles, ideologies, epistemological assumptions, etc. of their discourse (their documents) over time " (38).

In addition, within discourse communities there are neophytes who gradually have achieved a great expertise (Bhatia, 1993, 2004; Swales, 1990). Therefore, within these communities expertise may be dynamically acquired from the constant discursive interaction within the discipline (Parodi, Venegas, Ibanez and Gutierrez, 2008).

According to Castro, Hernandez and Sanchez (2010), the academic context is unique in the type of interaction that it promotes. From an expertise view, the student is usually identified with the image of a novice or apprentice as opposed to that of the specialist.

\section{Epistemic writing}

If we understand academic literacy as the development of reading and writing competence in a disciplinary field, the learner generates knowledge 
in a progressive way, that is, the student goes through various levels of writing, from a reproductive to a more elaborated and epistemic one. Being literate, according to this epistemic conception, means having the ability to act on knowledge, to transform it, which is possible for those who have the necessary tools. Thus, literate culture is seen as a higher level of language use - in this case writing - and thought, as well as the skills developed at an expert level, such as exploration and evaluation. In this context, writing should not be considered as an instrumental tool, but as a competence that allows to construct knowledge in its epistemic role, that is to say, to develop the potential that writing has to transform and communicate knowledge, which is an important aspect in the world of science and humanities.

In this regard, it has been pointed out that the epistemic value of writing lies in literacy itself, since this value does not necessarily produce changes in style nor in learning outcomes on its own, as has been traditionally understood (Villalón \& Mateos, 2009; Olson, 1998; Marti, 2003; Tynjala, Mason \& Lonka, 2001).

Academic and scientific writing is intrinsically epistemic, an inevitable and natural consequence of the composition process itself, which depends on the writer's level of competence. This is considered in the different writing teaching models proposed in the 1980s (Flower, 1979; Bereiter \& Scardamalia, 1987, 1993). Competent writers tend to be epistemic writers. They not only learn or modify their knowledge on the subject or content of what they write, but also improve their discursive knowledge. In other words, as Miras (2000) argues, the writer who uses this writing strategy not only learns about what he writes, but also learns to write. As Boscolo (1995) points out, what characterizes an expert in any field is that he not only solves a problem, but also learns from the solution. Using more epistemic writing strategies depends on the interaction among task, context and writer.

When addressing the writer's characteristics, from social-cognitive and sociocultural approaches, it has been highlighted the importance of the meaning that writers attribute to their activities as a determining factor in the cognitive process they unfold while writing. For example, the perception of students about their own competence in writing has shown great predictive power on both the processes carried out and learning outcomes achieved (Pajares, 2003; Bruning \& Horn, 2000).

\section{Genres in the university context}

Bakhtin (1986) has explained the relationship between genres and the sociocultural dimensions of the spheres of human activity. This activity is carried out with and in language, which is why genres, in terms of how they are used, are multiform, dialogical and situated. These genre characteristics are fundamental when addressing genres that circulate throughout the teaching and learning process of the disciplines comprising the curriculum of the undergraduate program examined herein.

New Rhetoric, put forth by Freedman and Medway (1994), among others, also situates student writers in the social, cultural and epistemic context - in this case, that of academic disciplines in undergraduate programs - in such a way that every student can learn how discourse is used through direct contact with the rhetorical situation to which it is responding. Bazerman (2004) also added to this line of argumentation by conceptualizing genres as part of larger genre systems, which are similar to the concept of academic literacy, in that it is a complex system of typified actions linked to a situated activity. The author states that genre is much more than the sum of its textual parts:

\footnotetext{
The definition of genre only as a set of textual features ignores the role of individuals in using and making meaning. It ignores differences of perception and understanding, the creative use of communications to meet perceived novel needs in novel circumstances, and the changing of genre understanding over time (Bazerman, 2004: 317).
}

Finally, the Sydney School, according to Martin (1992), posits that "genre is a schematically structured, staged, goal-oriented social activity" (505) and adds: "In these terms, as a level of context, genre represents the 
system of staged goal-oriented social processes through which social subjects in a given culture live their lives" (Martin, 1997: 13).

In addition to the aforementioned conceptualizations, it is important to mention, for the purpose of organizing genres in the university milieu, the concept of activity systems that Engeström, Miettinen and Punamäki (1999) developed by using the relationship between subject, object and instrument established by Vygotsky, extending this concept to activities, the social norms that guide activities and the division of labour that all activities imply.

To that end, Camps and Castelló (2013) examined how this posture affects the organization of genres in the university, considering that, in this context, writing is closely linked to the educational function of the institution. Furthermore, this function tends to determine the functionality of written discursive practices in which students as well as professors participate, and has a direct correlation to researchbased practices. As a result of this interrelation, activity systems emerge and are then subdivided into subsystems associated with the different disciplines, and scientific and professional fields in question. The two authors argue that the organization of genres used in the university should account for the different activity systems that characterize the communities of which they are part. One of those systems - the activity of teaching and learning - directly concerns this study, insofar as what is read and written therein is at the service of learning. In this sense, writing is linked to the elaboration, construction, negotiation, and reflection of knowledge, as well as to the evaluation of content learned.

In this regard, Carlino (2013) argues that in the Latin American context we must take care of literacy practices in the academic context and for this, within a genre-based teaching approach, it is important to differentiate instructional genres from expert genres. While both categories have continuities and dependencies, they most clearly differ in their contrasting aims. Instructional genres aim at instructing, introducing and evaluating those who are entering disciplinary cultures (Nesi \& Gardner,
2012), while expert genres are aimed at constructing, communicating and negotiating knowledge common to a given disciplinary culture (Navarro, 2014).

Therefore, if the predominant writing practices serve to validate acquired knowledge, then we are dealing with instructional genres; however, if the practices aim more at evaluating the level of disciplinary integration, then they can be considered expert genres. In general, the former genres circulate more in an educational context, consisting of tests (in class or take-home), reading responses, essays, and research projects, whereas the latter gravitate more towards the academic-professional context, i.e. papers, research grants and portfolios.

In order to understand the kinds of epistemic practices students are learning in their course work, we examined from a qualitative approach how teachers and students visualize literacy in academic writing in undergraduate programs in Science (Biochemistry, Biology and Mathematics) and Humanities (History and Art) at a Chilean university, and also, what genres circulate in those disciplinary communities. To do this, researchers and qualified technical staff enter the field and interact with the different informants as well as with the academic community in order to collect the necessary information through semi-structured interviews and focus groups.

The transcriptions of the material collected, the coding process, analysis and interpretation of the results, as presented in the following pages, have constituted a significant corpus that has not only motivated dissemination to the participating communities but also to the sponsoring institution. Finally, there is no doubt that in these communities academic literacy is carried out through a deep nexus between writing, knowledge and learning within a particular academic field.

\section{Research Questions and Objectives General research question}

- How is literacy in academic writing addressed based on the approach to the genres circulating in the disciplinary communities? 


\section{Specific research questions}

- How is literacy in academic writing conceived within the disciplinary communities of Art, Biochemistry, Biology, History and Mathematics at a Chilean university?

- Which academic genres are recognized in each of the disciplinary communities?

- How are these academic genres described?

- Which epistemic practices are associated with these genres?

\section{Methodology}

This work is framed in a qualitative and exploratory approach. As has been mentioned above, its main objective is to determine based on the genres that circulate at a Chilean university. To account for how literacy in academic writing is addressed in the disciplinary communities of Art, History, Biochemistry, Biology and Mathematics we needed to identify the genres that circulate in each of these disciplines, and determine the way literacy in academic writing is conceived. In both cases, the process of gathering information will be addressed based on teachers' and students' Social Representations (SR) (Jodelet, 1986).

It should be pointed out that, for the purposes of this study, a SR will be conceived as a belief that someone may have about the issue at hand, and that is identifiable in the discourse of teachers and students through the different coding procedures that entail content analysis. That is to say, the SR in this case has a declarative character, being the way reality is reconstructed. Finally, it is worth mentioning that we need to consider the characteristics of individuals' representations, since they will determine the way they will face a given task, theme or problem (Gonzalez \& Rivera, 2009). As Araya (2002) argues, the importance of addressing a social phenomenon from the SR perspective is that it: permite reconocer los modos y procesos de constitución del pensamiento social, por medio del cual las personas construyen y son construidas por la realidad social. Pero además, nos aproxima a la "visión de mundo" que las personas o grupos tienen, pues el conocimiento del sentido común es el que la gente utiliza para actuar o tomar posición ante los distintos objetos sociales (12).

In other words, this construct allows us to understand how interactions within a given community occur as well as the reasons that motivate them, because, as Abric (2001) states, representation, discourse and practices are mutually generated.

In summary, social representations (SR) are, first of all, both a product and a process of an external reality appropriation activity and of a psychological and social elaboration of that reality. Second, they would be on the basis of knowledge socially elaborated and shared, and constituted based on the experiences, information, and models of thought that are received and constructed. Finally, they would be the practical knowledge that is part of a group's social construction of a common reality and that intends to essentially dominate that environment, understand and explain the facts and ideas of our universe of life (Jodelet, 1986).

Finally, the data collected were processed using the procedures of content analysis technique, as they allow us to obtain the latent content of the collected information. Addressing the latent content allows to relate the set of coded data and integrate them into higher-level interpretations to establish relationships and theoretical inferences among the issues being investigated, the object of the study and researcher assumptions (Maryring, 2000; Cáceres, 2003). As Piñuel (2002) states, content analysis technique consists of:

un conjunto de procedimientos interpretativos de productos comunicativos (mensajes, textos o discursos) que proceden de procesos singulares de comunicación previamente registrados, y que, basados en técnicas de medida, a veces cuantitativas (estadísticas basadas en el recuento de unidades), a veces cualitativas (lógicas basadas en la combinación de categorías) tienen por objeto elaborar y procesar datos relevantes 
sobre las condiciones mismas en que se han producido aquellos textos, o sobre las condiciones que puedan darse para su empleo posterior (2).

It is noted that, given the nature of this study, the obtained results are not generalizable to other academic communities from other educational institutions.

\section{Sample}

Sample gathering was carried out using the snowball sampling technique (Bonilla-Castro \& Rodriguez, 2005). First, we contacted the directors of the target communities, who then referred us to the other two informants, the teachers and their respective students.

Data collection was carried out through either indepth interviews or focal groups. The decision to use one method or the other was made according to the participants' availability and/or preferences.

The specifications of the data analyzed are presented in the following table:

\begin{tabular}{|c|c|c|c|}
\hline Discipline & $\begin{array}{l}\text { Data collection } \\
\text { method }\end{array}$ & Subjects & $\begin{array}{l}\text { Number of } \\
\text { interviews/ } \\
\text { focus group }\end{array}$ \\
\hline \multirow[t]{2}{*}{ Arts } & Interview & Teacher & 3 \\
\hline & Focus group & Student & $\begin{array}{l}1 \text { ( with } 3 \\
\text { subjects) }\end{array}$ \\
\hline \multirow[t]{2}{*}{ Biochemistry } & Interview & Teacher & 6 \\
\hline & Focus group & Student & $\begin{array}{l}1 \text { (with } 6 \\
\text { subjects) }\end{array}$ \\
\hline \multirow[t]{2}{*}{ History } & Interview & Teacher & 7 \\
\hline & Interview & Student & 5 \\
\hline \multirow[t]{3}{*}{ Mathematics } & Focus group & Teacher & $\begin{array}{l}1 \text { (with } 5 \\
\text { subjects) }\end{array}$ \\
\hline & Interview & Student & 1 \\
\hline & Focus group & Student & $\begin{array}{l}1 \text { (with } 5 \\
\text { subjects) }\end{array}$ \\
\hline \multirow[t]{2}{*}{ Biology } & Interview & Teacher & 9 \\
\hline & Focus group & Student & $\begin{array}{l}4 \text { (with } \\
2,6,5 \text { y } 4 \\
\text { subjects, } \\
\text { respectively) }\end{array}$ \\
\hline
\end{tabular}

Table 1. Sample characterization
For both methods, interviews or focus group, the questions that guided the conversation were:

- What texts do students write along their major programs?

- Is writing taught or practiced? If so, how is it done? Why?

- Tell us about the last writing activity in which you were involved at university. What did you do? How did you do it?

- What role is given to writing activities?

\section{Analysis procedure}

First, recordings of the interviews and focus groups were transcribed and separated according to conversation turns, in order to make the analysis process easier. In addition, a number was assigned to each of them to facilitate subsequent search in case we need to reference examples.

Then, we identified the registration units in the corpus, that is, those analyzable parts that had relevant content to the aims of this study. In this case, our interest is in all the information related to the following variables:

\begin{tabular}{|l|l|}
\hline Variable & Description \\
\hline $\begin{array}{l}\text { Mode of } \\
\text { writing } \\
\text { work }\end{array}$ & $\begin{array}{l}\text { For our purposes, the interest is in how } \\
\text { writing activities are set, whether students } \\
\text { were given time during lessons to perform } \\
\text { them, or, on the contrary, whether they do } \\
\text { it outside classroom time. }\end{array}$ \\
\hline $\begin{array}{l}\text { Role of the } \\
\text { teacher in } \\
\text { writing }\end{array}$ & $\begin{array}{l}\text { Through this aspect, we sought to } \\
\text { recognize the degree of involvement of } \\
\text { teachers in the development of writing } \\
\text { activities, that is, if they only gave the } \\
\text { instructions, or if they guided the process, } \\
\text { gave advice, monitored the activity, etc. }\end{array}$ \\
\hline
\end{tabular}




\begin{tabular}{|l|l|}
\hline $\begin{array}{l}\text { Form of } \\
\text { evaluation } \\
\text { and } \\
\text { correction } \\
\text { of writing }\end{array}$ & $\begin{array}{l}\text { The interest was in knowing how the } \\
\text { process of evaluation and correction } \\
\text { of writing activities is carried out, for } \\
\text { example, what kind of instrument was } \\
\text { used, how teachers gave feedback about } \\
\text { the activities, at what moments this was } \\
\text { done, etc. }\end{array}$ \\
\hline $\begin{array}{l}\text { Genres } \\
\text { that } \\
\text { circulate } \\
\text { in the } \\
\text { community }\end{array}$ & $\begin{array}{l}\text { All genres that are mentioned by the } \\
\text { disciplinary community are recognized. } \\
\text { Here, it is important to consider their } \\
\text { characterization, since it allows to } \\
\text { correlate the names given by the different } \\
\text { specialists and students, as well as their } \\
\text { characteristics. }\end{array}$ \\
\hline
\end{tabular}

Table 2. Identification and description of variables in the corpus.

For the purpose of simplifying the analysis, each one of these units was paraphrased, keeping the information that is useful for the investigation.

Later, we carried out the coding process, assigning categories to each of the identified register units. This procedure is named microanalysis and it is based on a line-by-line work, although it is also possible to apply it to a word, sentence or paragraph. For this reason, it is possible that a registration unit contains more than one category according to its content. In this stage the gathered information was constantly compared, so that different units addressing a common concept, procedure and/or content could be related and, consequently, the data could be homogenized.

One example of the coding process described is presented in the following table:

\begin{tabular}{|l|l|l|}
\hline Registration Unit & Paraphrase & Category \\
\hline $\begin{array}{l}\text { "we do projects, } \\
\text { so they have to do } \\
\text { fieldwork, collect } \\
\text { data and then } \\
\text { make a project } \\
\text { formulation, first, } \\
\text { by making a sample } \\
\text { design, doing field } \\
\begin{array}{l}\text { work, collecting } \\
\text { data." }\end{array}\end{array}$ & $\begin{array}{l}\text { Students must } \\
\text { to collect data } \\
\text { and formulate a } \\
\text { sample design } \\
\text { project. }\end{array}$ & $\begin{array}{l}\text { Project } \\
\text { formulation }\end{array}$ \\
\hline $\begin{array}{l}\text { "They have to make } \\
\text { a final report as a } \\
\text { scientific work, that } \\
\text { is what they do." }\end{array}$ & $\begin{array}{l}\text { Students } \\
\text { elaborate a } \\
\text { report as a } \\
\text { scientific work. }\end{array}$ & \\
\hline
\end{tabular}

\begin{tabular}{|l|l|l|}
\hline $\begin{array}{l}\text { "[about the report] } \\
\text { yes, it is taught, it } \\
\text { is done throughout } \\
\text { the semester, so it is } \\
\text { explained to them." }\end{array}$ & $\begin{array}{l}\text { During the } \\
\text { semester } \\
\text { teachers } \\
\text { explain to } \\
\text { students how to } \\
\text { make a report. }\end{array}$ & $\begin{array}{l}\text { Instructions to } \\
\text { write a fieldwork } \\
\text { report }\end{array}$ \\
\hline $\begin{array}{l}\text { "We correct from } \\
\text { writing, expression } \\
\text { of ideas, project } \\
\text { formulation," }\end{array}$ & $\begin{array}{l}\text { Writing } \\
\text { and project } \\
\text { formulation are } \\
\text { corrected. }\end{array}$ & $\begin{array}{l}\text { Correction } \\
\text { aspects in the } \\
\text { project }\end{array}$ \\
\hline
\end{tabular}

Table 3. Example of coding procedure of writing segments

Finally, the repetition of the categories raised in the sample according to each community was reviewed, removing information that is not significant in this regard. The importance of this task is that it will determine, on the one hand, when it is an individual representation and when a SR, and, on the other, what the genres circulating in the communities are. To raise and homogenize data related to genres, first, the name or label used by community members was identified; second, the characterization they made of these genres was formulated, to establish relationships and find similarities among the named genres. Finally, respondents were asked to confirm a sample of the genres.

\section{Analysis and Discussion}

In this section, we present the analysis of the data regarding the identification of genres circulating in each community and their conceptions in relation to the ways of tackling literacy in academic writing.

\section{Undergraduate Program in Arts}

Within the community of Arts three different subdisciplines coexist in the same undergraduate program: Visual Arts, Art History and Art Theory. Important differences were detected between the first and the last two programs in the two aspects our analytical work focuses on. In all three subdisciplines, the majority of the genres identified from the SR of teachers and students are instructional, but the ensayo is the only one that appears in the 3 sub-disciplines, without major changes. This genre aims at critically reflecting 
and / or interpreting a phenomenon, concept, resource or artistic expression (depending on the subject area that is being developed) and its predominant mode of discourse organization is argumentative. As some students comment:

For example, in Art Theory, they teach you about the structure of an ensayo (...) (ART / Focus, 8).

(...) in Art History, he [the teacher] in a way teaches you to focus an ensayo, so he makes you define the topic, hypothesis and all that, he helps you to organize yourself (ART / Focus, 13).

The book, however, appears uniquely in the Visual Arts, and does not circulate in other communities. Its purpose is to have students reflect on the compilation of works that they have done both during the creation process, and when it is ready to be exhibited to the public. It is multimodal, because it uses different materials (leather, wood, wool, aluminum, etc.) with an artistic purpose. Its mode of discourse is informative and narrative. The book corresponds to the end-of degree project to be submitted by students in this subdiscipline and it is the only genre in the community that resembles expert genres. One student comments:

I paint, and everything I have painted and what influences my work, all that is in my Book, it's like... this is the first thing I painted when I was a kid, until this last one I did when I was grown up; then you put all the instances of that particular work, from when I was a kid, what has changed, how it is now (ART / Focus, 77).

Art History and Art Theory subdisciplines share three academic genres that do not appear in the Visual Arts. The first is called biografema, and requires connecting the creation of an artistic work to an aspect or particular events of the biography of the author. Its predominant mode of discourse is narrative and it is also known in the community as texto-artista. Then there is the diccionario, recording the definition of concepts used in the community and that are relevant to the analysis being made of an art work. Its predominant discursive organization is informative. Finally, we find the informe de investigación, which seeks to discuss a research problem using the historical method. It can also be regarded as an instructional genre, in which an argumentative-informative mode of discourse is recognized. One teacher comments:

[...] I have them prepare a diccionario, with art words, philosophical words, important words, not all of them are artistic words but decisive words about what they [students] want to do. So I teach them to stop and think of words [...] but besides, for every word I tell them to give a personal opinion or to add something meaningful, like an artistic mark (ART / Interview 1, 4).

In Art Theory, the end of the term project follows the same structure and rhetorical organization of the ensayo and, in Art History, it follows the informe de investigación, using historiographical methodology. Both the ensayo and the informe de investigación are instructional genres, unlike the book, as explained above.

Regardless of the subdiscipline concerned, all the genres have a strong formative orientation, which students themselves recognize along with the role of the instructor in providing guidance. For example, one student comments:

\begin{abstract}
In history, we must write, for example, an article and it must have a very determined structure, the teacher would give you guidelines stating you need to have paragraphs, some of them of a given extension, how the written part goes, as well as the images, and she would give you themes you had researched before, and also themes you had presented about before. So, it all depends on the teacher. In Theory, for example, the teacher would help us by working with us, having some meetings to talk about the ideas we are working on, he would guide you and he would never say "No, this is wrong", he would give you bibliographic references, and help you to develop your theme (ART / Focus, 32)
\end{abstract}

These guided exercises help the students develop their written competence while they familiarize the students with the methodology underlying each 
subdiscipline and its particular way of writing. An instructor comments:

I am an art historian, other colleagues are philosophers, so the entrance is different, say Philosophy has its own idiolect and its own concepts, their own semantic basin which is different from Historiography, then students need to conciliate these different views and also write in a different way (ART / Interview 2: 8).

The main difference between the sub-disciplines lies not only in the fact that they have exclusive genres, but in the importance that the genres have within the communities. In the Visual Arts - with a more applied approach - each of the productions made by the student will shape his style and his future career. This is mainly recognized in the book, because, as was mentioned above, it works as a portfolio in which it is possible to browse through works, proposals or art interventions carried out during the student's' academic formation. It also serves as a way for the student to be known from a personal perspective and to set up his artistic graduation project.

In the undergraduate programs in Art, Art Theory and Art History (with a more theoretical approach) written production is carried out as an exercise that does not transcend the academic community and that is focused on showing a portion of specialized knowledge. For example, through the development of research reports or essays students are asked to investigate an artistic phenomenon or to pose a research problem that can be analyzed through the relation of various literature sources. In this case, the focus would be much more on learning the methodology of each area, which brings them closer to a formative approach of the discipline. It is also possible to recognize some support specialists give novice community members.

\section{Undergraduate Program in Biochemistry}

Both teachers and students recognize that the proyecto de investigación moves towards the expert genres. As its name implies, its purpose is to propose an investigation about a problem posed based on the student's observations; its mode of discourse organization is predominantly argumentative and it arises from a question raised in that is appropriate to the formulation of a project. This genre brings the student close to the demands of his professional life. As one teacher comments:

Because in science, one tries to convince the other of what you want to do is feasible, it's like, (...) approve the proyecto de investigación to have funds and carry it out (BIOQUI / Interview 3, 35).

The informe técnico aims at checking / rejecting a hypothesis about an issue raised by the teacher, from the specialized and updated bibliography review. Its mode of discourse organization is predominantly informative, although argumentative segments are recognized. As a student comments:

In the informe técnico a hypothesis should or should not be verified. You also have to compare the experimental data with the theoretical data, then see the theoretical data with calculations that there are many that are chemical-theoretical, but if one supports it with the experiment done and they match, more importance the work has (BIOQUI / Focus, 116).

This informe técnico is drawn from a series of prereports, each of which is associated with a specialization in Biochemistry; that is, these pre-reports are not conceived as intermediate steps towards a final product, but as various subdisciplinary areas that converge in the informe técnico in the community of Biochemistry. One teacher describes this:

[...] three areas of biochemistry are integrated, the student, through a problem, a particular issue in Biochemistry, has to develop the project in stages to elaborate the informe técnico, then the stages are also divided into three, according to the specialties that one expects the students become proficient in [...], so they at an early stage make a characterization of the enzyme, [then] they purify it and then make physiological applications with another teacher and so, there they write for each teacher (BIOQUI / Interview 4, 20). 
Likewise, the informe de trabajo experimental is identified, which meets the objective of recording relevant aspects of the development of a laboratory work. The dominant discursive mode is informative and it includes tables, diagrams and / or drawings. One teacher comments:

Well, the informe de trabajo experimental is evaluated based on the quality of the experimental work itself and the quality of the presentation of results and their consistency with what was raised and what was done, and if consistent information is drawn upon the results (BIOQUI / Interview 6, 20).

Apart from the proyecto de investigación and both informes, the community recognizes two kinds of instructional genres, mainly academic. The first one, the prueba, has the purpose to demonstrate specialized knowledge, especially from the integration of sources. The second, the tesis, develops an end-of-degree research project based on an experimental laboratory work. Its predominant discourse modality is informative, with clearly argumentative segments, especially those related to the analysis and discussion of the data.

As in Biology, students write in Biochemistry to acquire the particular method of work of this science; although, in this case, there is no support from teachers to deal with this learning process. Overall, this is because teachers believe that the teaching of writing in higher education is not something they should be responsible for.

Teaching writing is part of the competences students should bring, because we can not dilute time devoted to a specialty in going back and form what was not previously formed [...] We can not devote time in teaching something that should have been taught previously at school, it is something learned at school, at home, the world that has surrounded the students, because there are guys whose parents are good readers and they read a lot and, there is the answer, even if at school they did not learn anything, they end up learning to write anyway (BIOQUI / Interview 5, 92).
Precisely, the lack of support and formative orientation is what is recognized from the analysis of the SR of the community members. One teacher comments:

We don't teach them how to write, but in every course we read a lot of papers, so they get familiar (BIOQUI / Interview 3, 13).

Considering the specificity of the genres that have been mentioned and that teachers generally do not provide support in the development of these writing activities, students are forced to rely on their intuition to comply with what they are required to do, clinging to what they know. A student comments:

It is said the work must have the paper format, then one assumes what the format is because we have read a lot of papers, we already know that (BIOQUI / Focus, 17).

The above statement highlights the strategy used by the community newcomers: the observation of models.

Finally, it should be noted that, although in this community genres that move towards the expert types are recognized, the texts produced are not considered an advance in the knowledge of the discipline. In fact, the only possibility for these texts to transcend is ascribing them to a research project developed by the teachers of the community. In this case, they would serve as part of the input for a scientific publication, but may not constitute one by themselves.

\section{Undergraduate Program in History with a minor in Political Science}

In the History community, internal differences among the teachers result in different ways of dealing with writing activities. Thus, it is possible to consider a traditional school and a new or interpretive one. Despite this difference, the genres that were identified were cross-disciplinary. One key instructional genre is the control de lectura, which aims to record the critical analysis of historical facts based on a given literature, 
guided by one or more questions. The discourse organization is eminently informative.

The student reads and has to take controles de lectura, because most of the exercises of this kind is to control whether the student reads or not and if he understands the idea HIST / Interview / Professor 5, 4).

Another recognized genre is the ensayo, which aims to discuss a historical problem, relying on specialized literature, with a prevailing argumentative discursive mode. Finally, the tesis, an end-of-degree work that shares the same purposes and mode of discourse as that of the ensayo.

[...] and its main purpose is essentially to present a set of ideas and to argue based on that set of ideas. That is the most recurrent kind of written text, this is the kind that, as I tell you, I don't know if ensayo is the right word, but in the end, it is from that set of ideas that arguments are posed, possibly solving some hypothesis (HIST / Interview / Professor 7 79).

Among the closest genres to the expert category, we find the artículo de investigacion and the poster. The former makes an in-depth investigation of a historical event with support from various sources, especially primary sources, and whose prevailing discursive mode is argumentative. The latter aims at disseminating research conducted in the discipline. It usually uses various semiotic modes and comes from other discourse communities (Science, Engineering).

Within the interpretative school identified in this community, stands out the support given by teachers, who generate instances to give feedback and guide the writing work, so that the students manage to learn the conventions of the discipline. As two teachers comment:

Then, students present what they have analyzed and I also take this opportunity to make some observations and complementing a little the interpretation of the text. And then that reading is part of the subject matter of the course (HIST / Interview Professor 7, 42, 44).
In general, before they submit their work I ask them to present to the class about what they have done, and of course, those who want to make comments or suggestions can do it in this instance (HIST / Interview / Professor 4, 26).

In many cases the teacher aids in each of the courses, provides the primary support for the students in their process of integration into the community.

By contrast, within the traditional school identified in this community, the instructors themselves tend to have a more prescriptive orientation, pointing out how things should be done in the discipline, without explaining why they work this way. These instructors focus on evaluating the knowledge gained rather than recognizing the degree of insertion of helping students integrate into the specialty.

Then in some courses students have to do some short research, which are essentially bibliographic, $[\ldots]$ depending on the extensions. There they also write texts, but, as I say, bibliographic and [...], not necessarily in these exercises it is explained, in my view, what a scientific text should be like, nor are they shown types of texts, from a paper, a report, the formulation of a project or essay. Then, it is assumed that students should write texts, but they are not told that there are different types of texts (HIST / Interview / Professor 5, 6).

A fundamental part of the problem is that students, in their final years of study, are expected in their tesis to contribute to the disciplinary knowledge, even though they were never guided on how to construct their texts in class, nor were the tasks properly contextualized according to their future work as researchers. Against this prescriptive scenario, students must generate their own strategies to meet these demands:

I was inspired to write the sections from other tesis [...]. But it was not like the teacher gave me a paper and said "There's the structure ". No. Then I clinged to what I had been taught about doing smaller research work. Then I saw other tesis. And it also helped me the things I talked about with other classmates who were writing their tesis too (HIST / Interview / Student 2, 20). 
Despite these difficulties, the texts produced by the students are recognized as contributing to some extent to the development of knowledge in their area. This is especially seen in ensayos, artículos de investigación and tesis students must produce throughout the program, since, even though sometimes they study events or sources that have already been addressed by specialists, a change in the approach or point of view can help to raise new issues.

\section{Undergraduate Program in Mathematics}

In this community three genres are recognized, which correspond to the so-called instructional genre category. In the first case, we find the prueba, which aims at recording the acquired knowledge and learning related to solving mathematical problems. Its discursive mode is predominantly informative, but it can sometimes be argumentative. It uses various multimodal artifacts and uses mathematical language. There are two types according to the resolution time, the place in which it develops (in class or outside), the complexity of the required skills, and the depth of analysis necessary to answer them:

You learn, through the different pruebas and assignments, how teachers correct and the writing style they consider the best [...] but one gets to self-correct through practice, and pruebas (MAT / Interview / Student, 39).

The second genre is the tesis, which aims at establishing the research capacity in the discipline based on the discussion of a mathematical problem. Its prevailing discourse mode is argumentative:

Sometimes the problem is that, as Mathematics is a rigorous discipline, we must use accurate language, then if writing is vague, it leads to inconsistencies, then we reject and then demand an explanation from a mathematical point of view, and then we have them rewrite a paragraph of the tesis (MAT / Interview / Professor 2, 6).
The last genre identified is the paper, which aims at discussing a published mathematical research and communicating the findings to the community. Its dominant discourse mode is argumentative.

Respondents agree that the teacher plays a guiding role in the production of written texts, as he or she constantly monitors the work students are doing, by revising, editing and providing models so that students can achieve a better final written text:

Let him explain something to you, he finds what he is saying is not the same as it is written in words. Or you, if you can confront what he said, in mathematical terms, to see if that is exactly what is written in words and, sometimes, he realizes that is not so, it is not so clear, but not because he does not have a clear idea, but it is because of the way it is expressed (MAT / Focus / Professor, 22).

From the discourse of the informants, it is possible to establish that this constant support in the production process is due to the intervention of two different codes in the discipline: the mathematical and the verbal code. In this case, the problem is that students initially fail to express their ideas in words but transform them into numbers or symbols:

\begin{abstract}
Students tend to work with formulas, almost no one writes one or two words, they tend to do it only with numbers and they think that's Math, when it's not really that, in fact, it is a logical science that can be written completely without any symbolism (MAT / Focus / Professor, 14).
\end{abstract}

As a consequence, sometimes when they write using the verbal code, they pose something completely different from what they express when using the mathematical one. Given this situation, teachers are obliged to help them improve this aspect so that they can be integrated into the community:

He can manage mathematical concepts, but the difficult part is how he transmits them so that another person can read them (MAT / Focus / Professor, 16). 
In the Mathematics community a similar situation occurs to that described in the community of Biology, as the writing activities developed in the different courses are designed to learn the Bourbaki method, a convention that regulates the way in which the content of mathematical discourse is organized, and it also explains the reasonings applied when solving a mathematical problem:

We study theorems and demonstrations and all that has a structure, and we also study how they are written, for that we use logic. When we write, we write reasonings and there is a logical order in what is being written, according to how a certain theory is been developed (MAT / Interview / Student, 14).

Finally, it is important to note that, as was also found in Biology and Biochemistry communities, written productions of Mathematics students do not imply an advance in the development of knowledge in the discipline, because they develop themes which are already known in the discipline. That is, they are asked to take an issue or problem that has been addressed previously, or for which there has already been an answer, to demonstrate the knowledge they have acquired in their training process. For this reason, the texts produced will probably not be published, as the focus is on learning the proper method of the mathematical community:

What happens is that at the undergraduate level it is assumed that students have to write something with their own language, but that may be well-known in mathematics, they have to write in their own words, showing that they understand what they are proposing (MAT / Focus / Student, 130).

\section{Undergraduate Programs in Biology}

The community of Biology presents a situation similar to that in the two theoretical sub disciplines of Art. Here, the different writing practices aim at students acquiring the work and research methodology of the discipline. In this context, instructional genres are predominant, which ascribe to a formative framework, as the community seeks to promote the learning of the scientific method through the use of these genres.

In this community, three genres can be recognized. The informe de presentación asks students to record aspects of a research project planned by students, and is subsequently presented orally in front of their classmates and teacher. The predominant mode of discourse of this genre is informative, although sections use argumentative discourse. A teacher describes the activity:

To do that [make the informe de presentación] they work in groups, present orally to the whole group about what they are doing, what their idea is, and the class has the opportunity to give some feedback, whether it has some logic or not, they have to make 3 or 4 presentations (BIO / Interview 9, 37).

The second genre is informe de salida a terreno. It is intended to account for the data obtained from the observation of natural phenomena, according to a series of criteria that are previously established. In addition to observing, students must be able to analyze this information considering the content addressed in classes and research conducted on the phenomenon in similar contexts. Their mode of discourse organization is predominantly informative and uses images to support verbal language. The instructor comments:

They have to do fieldwork, collect data and make a project formulation, first by making a sample design, collecting data and making a final report as scientific work (BIO / Interview $4,61)$.

Finally, the third genre identified is the paper. The way this discursive manifestation is addressed in the community varies depending on the students' year of study, because, even though the structure remains the same, the demands and the ultimate purpose of the text change. Thus, in their first year, students must write a paper that meets the primary objective of persuading their instructor about their research competences, based on an experiment carried out by the students 
themselves, or based on a published experiment, which students replicate with some variations on either the biological sample or local context, applying the particular scientific method used in Biology. However, they are expected to do this without an exhaustive review of literature sources. By contrast, in their final years students are expected to discuss concepts, theories and studies, for which the reviewing of sources of information is essential. Despite these differences, all the genres identified correspond to the instructional type, as their communicative purpose is the instruction and assessment of individuals entering the disciplinary communities.

As to how the work of writing of these genres is addressed, it should be noted that students report that they do not receive a direct instruction in this matter. According to the interviews and focus groups analyzed, it is common to guide the work done by students through oral comments or written marks on texts, which, undoubtedly, would allow the students to adapt their discourse to the practices, requirements and needs of the academic community they are becoming part of. However, no formative work nor direct support is acknowledged. One teacher comments:

In a laboratory, we practice elaborating a summary, then presenting it, and writing results. It's like doing everything separately, sometimes we are dedicated only to the results, or only to interpret results, or only to write methodology, to analyze methodology and then to write methodology (BIO / Interview 8, 24).

This contrasts with the instruction in Physics, where students report a much more guided process for acquiring genres. In Physics models are displayed and guidelines and evaluation rubrics are given to students. Even though our study does not address this discipline, one student made the contrast.

In second year, we had, as I told you, we had to do all the laboratories in Physics, but there the teacher spent a whole laboratory class to explain how to make a paper, that is, she said 'this is how you do it', hypothesis, everything, and she gave us a guide ... a sheet of paper with all the steps, examples and everything (BIO / Focus 4,56 ).

Finally, it is important to reiterate that all writing exercises done by students aim at acquiring the discipline's own research method; therefore, the texts produced do not have a real importance other than meeting the requirements of the subject they are studying. For example, the papers they may produce would not fulfill the requirements to be published in specialized journals. This is because both the investigations the students carry out are much more delimited than those made by experts, and within the discipline, knowledge is communicated in English, a language barrier that students do not manage to overcome in the undergraduate program:

The only thing they asked for was that the data were real, that they were the result of our research, that they follow the guidelines given in the webpage [ of the magazine], I do not remember the name right now [...]. But, as they were small investigations only to write the paper, I did not have high expectations either, so it was more a matter of getting the structure right (BIO / Focus 1: 37).

\section{Final comments}

From the SR identified in the discourse of teachers and students of the different communities described above, a number of genres have been recognized, most of them instructional genres. They have been described in operational terms based on the information provided by the community members. In addition, a rather small sample of expert genres has emerged. Among the instructional genres, some of them are present in all communities, for example, the ensayo, the informe and the prueba. Of course, some particularities have been identified in these genres, which are related to the characteristics of each discipline and its object of study. Other genres, however, are more specialized and unique to each community, namely the book, the biografema and the diccionario. 
In these communities, the discourse of teachers and students reflect two orientations toward academic writing: a formative approach and another more prescriptive. Both approaches are determined by the conception of the strategies used to address writing, which is evidenced in the discourses analyzed. In the formative approach, these strategies refer to assessing to what extent students have integrated in the community, whereas in the more prescriptive approach, they refer to corroborating the degree of knowledge acquired. The following figure illustrates both orientations, associated to the communities that were analyzed.

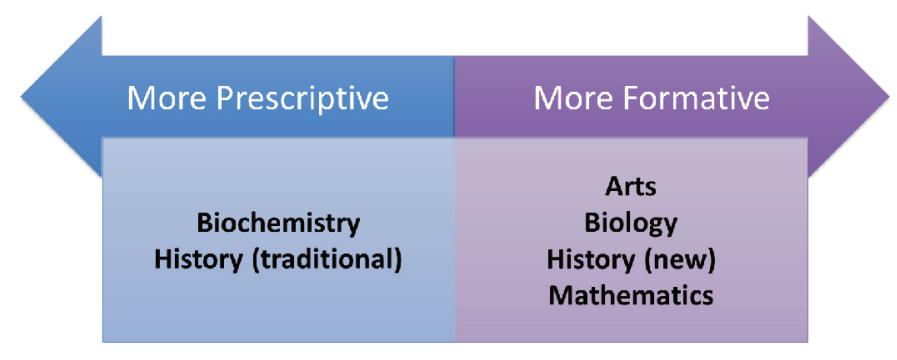

Figure 1. Orientation of academic writing literacy

Under the formative perspective, the genres recognized are those closest to the expert type, for example, the book, the biografema, póster or the diccionario. In this case, the focus would be on the student's formation and on helping them to be integrated in their disciplinary communities. As one teacher comments:

If they do not know how to write it's like they cannot think and if they cannot think, they remain outside the community [...] it is absolutely decisive (ART / Interview 1:8).

By contrast, from the more prescriptive approach, academic instructional genres are preferred, such as pruebas, ensayos and trabajos de investigación, ie, those that allow to prove to the teacher that the student has learned a certain content. One teacher comments:

They learn whether they did it well or wrong, if they did it wrong, they have to learn to do it well (BIOQUI / Interview 3, 13).
From the conception about academic literacy that is evident in every community, a defining feature of writing is identified: its epistemic potential.

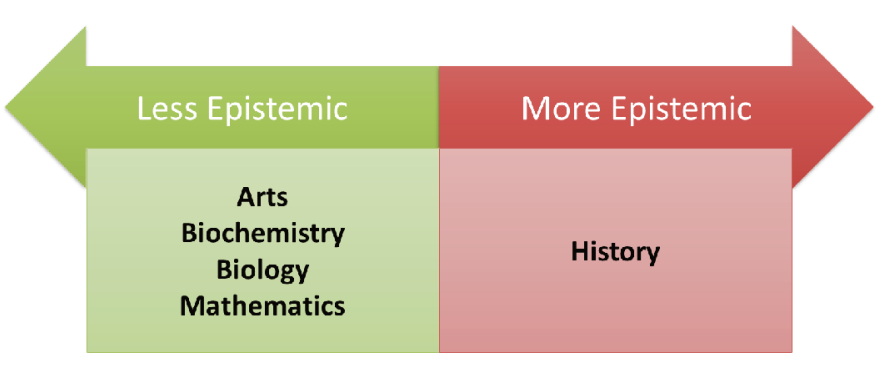

Figure 2. Development of epistemic potential in student writing

The development of epistemic potential becomes much more evident in those genres that project work far beyond the boundaries of academics, allowing students, on the one hand, to relate to the professional work and, on the other, generate new knowledge for the community.

Now, considering what was mentioned above, one might think that there are genres that are more appropriate for certain writing assignments according to their general characteristics. For example, one might assume those genres with a predominant argumentative discursive mode, such as ensayos, are more epistemic as they seek to generate a reflection from a series of ideas. However, a prueba, which can be considered simpler than an ensayo, at the university level can be purely reproductive or may require the orchestration of more elaborate cognitive skills than the latter; or an informe de investigación that, beyond its goal of accounting for an investigative process, can take a more analytical character in the data discussion section. We must remember that the genres that were recognized in the different communities are ascribed to an accrediting framework, and they are instructional and expert - or at least close to that. Therefore, they are mainly used for evaluating disciplinary knowledge and for students to learn the specific modes of the community; in addition, it should be noted that the audience is almost always the teacher.

When connecting the conception of academic literacy (formative / prescriptive) with the epistemic 
nature of writing, the various communities can be articulated as follows:

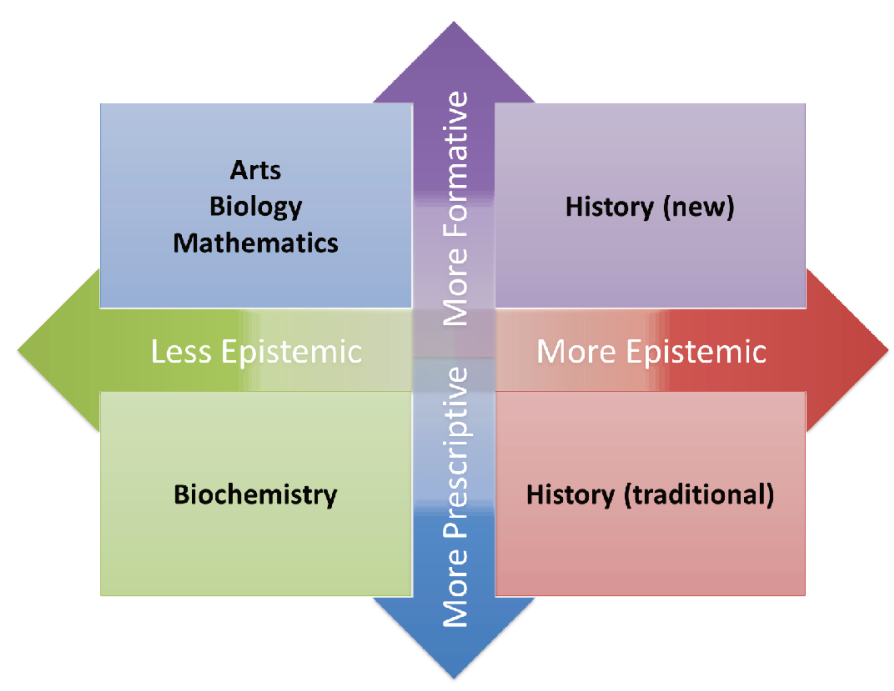

Figure 3. Relation between the orientation of academic literacy and the epistemic character of writing

The greater or lesser epistemic potential of academic writing has to do especially with the activities that are generated within each community and with the imprint made on the genres circulating in them. If the use of these genres promotes complex cognitive skills such as analyzing, distinguishing, ranking, inferring, interpreting or proposing, they will surely be closer to achieving the epistemic function of writing, whereas the opposite will occur if only less complex cognitive skills are practiced, such as reproducing, explaining, recognizing or defining.

In addition, the variations of the epistemic potential of academic writing have to do with the way the construction of knowledge within the disciplines is conceived. Thus, in Science, the different activities carried out operate under the concept of a dominant paradigm, understanding the term from the perspective of Kuhn (1969). From this view, it is very difficult for an undergraduate student to generate specialized knowledge relevant to the community. By contrast, in Humanities, where the contributions of novice researchers are acknowledged, the construction of knowledge follows a much more Bungean line (Bunge, 1983), because it is understood that the same object of knowledge can be seen from different perspectives. This makes possible the coexistence of more than one paradigm, since they are not incommensurable, because if so "al adoptarse una nueva teoría se haría borrón y cuenta nueva. La historia del conocimiento sería un eterno recomenzar: no habría progreso sino un zigzagueo" (Bunge, 1983: 6)

Finally, studying different undergraduate programs at a Chilean university from a qualitative approach has meant understanding the particularities of each program in terms of their worldviews and their discursive practices. In this regard, the conclusions drawn from this study are not generalizable but adjustable to the reality manifested through the discourse of teachers and students through semi-structured interviews and focus groups about the genres that circulate in the different communities they belong to and the way they address literacy in academic writing.

\section{Note}

1. This article was made possible in part by the FondecytConicyt (Chile) research grant no 1151171. This text was translated from the original Spanish. This includes quotes from non-English-language sources.

\section{References}

Araya, S. (2002). Las representaciones sociales: Ejes teóricos para su discusión. In Cuaderno de Ciencias Sociales, 127: 1-84.

Abric, J. C. (2001). Metodología de recolección de las representaciones sociales. In J. C. Abric (Coord.), Prácticas sociales y representaciones sociales (53-74). México D. F.: Ediciones Coyoacán.

Bakhtin, M. (1986). Speech genres and other late essays. Texas: University of Texas Press.

Bazerman, C. (1988). Shaping written knowledge: The genre and activity of the experimental article in science. Madison: University of Wisconsin Press.

(1994). Systems of genres and the enactment of social intentions. In A. Freedman \& P. Medway, Genre and New Rhetoric. London:Taylor \& Francis. 67-86.

(2004). Speech acts, genres, and activity systems: How texts organize activity and people. In C. Bazerman \& P. Prior (Eds). What Writing Does and How It Does It: An Introduction to analyzing textual practices. Mahwah, NJ: Lawrence Erlbaum Associates. 79-101.

Bereiter, C. \& Scardamalia, M. (1987). The psychology of written composition. Hillsdale, NJ: Lawrence Erlbaum Associates. 
112 Juana Marinkovich, Marisol Velásquez, Alejandro Córdova and Carolina Cid, Academic Literacy and Genres...

(1993). Surpassing ourselves: An inquiry into the nature and complications of expertise. Chicago: Open Court Press.

Bonilla-Castro, E. \& Rodríguez, P. (2005). Más allá del dilema de los métodos: la investigación en ciencias sociales. Bogotá: Grupo Editorial Norma.

Boscolo, P. (1995). The cognitive approach to writing and writing instruction: A contribution to a critical appraisal. Cahiers de psychologie cognitive, 14(4): 343366.

Bruning, R. \& Horn, C. (2000). Developing motivation to write. Educational psychologist, 35(1): 25-37.

Bunge, M. (1983). Paradigmas y revoluciones en ciencia y técnica. El Basilisco, 15: 2-9.

Cáceres, P. (2003). Análisis cualitativo de contenido: Una alternativa metodológica alcanzable. Psicoperspectivas, 2: 53-82.

Camps, A. \& Castelló, M. (2013). La escritura académica en la universidad. Revista de Docencia Universitaria, 11 (1): 17-36.

Carlino, P. (2003). Alfabetización académica: un cambio necesario, algunas alternativas posibles. Educere, 6(20): 409-420.

(2006) Concepciones y formas de enseñar escritura académica. Un estudio contrastivo. Signo y Seña, 16: 71-117.

(2013). Alfabetización académica diez años después. Revista mexicana de investigación educativa, 18(57): 355-381.

Carter, M. (2007). Ways of Knowing, Doing, and Writing in the Disciplines. College Composition and Communication, 58(3), 385-418.

Castro, M. C., Hernández, L. A. \& Sánchez, M. (2010). El ensayo como género académico: una aproximación a las prácticas de escritura en la universidad pública mexicana. In Parodi, G. (Ed.), Alfabetización académica $y$ profesional en el siglo XXI. Leer y escribir desde las disciplinas (pp. 49-70). Santiago de Chile: Ariel.

Engeström, Y., Miettinen, R. \& Punamäki, R. L. (1999). Perspectives on Activity Theory. Cambridge: Cambridge University Press.

Flower, L. (1979). Writer-based prose: A cognitive bases for problems in writing. College English, 41: 19-37.

Freedman, A \& Medway, P. (Eds.) (1994). Learning and Teaching Genre. Portsmouth NH: Boynton/CookHeineman.

González, F. \& Rivera, M. (2009). Representaciones sociales sobre comprensión y producción de textos. Sonora: Universidad de Sonora.
Hyon, S. (1996). Genre in three traditions: implications for ESL. Tesol Quarterly, 30(4): 693-722.

Jodelet, D. (1986). La representación social: fenómenos, concepto y teoría. In S. Moscovici (Comp.), Psicología Social, II. Pensamiento y vida social. Psicología social y problemas sociales (469-495). Barcelona: Paidós.

Lave, J., \& Wenger, E. (1991). Situated learning: Legitimate peripheral participation. Cambridge: Cambridge University Press.

Lea, M. R., \& Street, B. V. (1998). Student writing in higher education: An academic literacies approach. Studies in higher education, 23(2): 157-172.

(2000). Student writing and staff feedback in higher education. Student writing in higher education: New contexts: 32-46.

(2006). The "academic literacies" model: Theory and applications. Theory into practice, 45(4): 368-377.

Kunh, T. (1969). La estructura de las revoluciones científicas. México: Fondo de Cultura Económico.

Martí, F. (2003). Representar el mundo externamente. La adquisición infantil de los sistemas externos de representación. Anuario de psicologíal The UB Journal of Psychology, 35(3): 425- 427

Martin, J. R. (1992) English text: System and structure. Philadelphia: J. Benjamin.

(1997). Analysing genre: functional parameters. In F. Christie \& J. R. Martin (Eds.), Genres and Institutions (3-39). London: Cassell.

Miras, M. (2000). La escritura reflexiva. Aprender a escribir y aprender acerca de lo que se escribe. Infancia y aprendizaje, 23(89): 65-80.

Navarro, F. (2014). Géneros discursivos e ingreso a las culturas disciplinares. Aportes para una didáctica de la lectura y la escritura en educación superior. In F. Navarro (Coord.), Manual de escritura para carreras de Humanidades (pp. 29-52). Buenos Aires: Facultad de Filosofía y Letras Universidad de Buenos Aires.

Nesi, H. \& Gardner, S. (2012). Genres Across the Disciplines: Student Writing in Higher Education. Cambridge: Cambridge University Press.

Olson, D. (1998). El mundo sobre el papel. Barcelona: Gedisa.

Pajares, F. (2003). Self-efficacy beliefs, motivation, and achievement in writing: A review of the literature. Reading \& Writing Quarterly, 19(2): 139158.

Parodi, G., Ibañez, R. \& Venegas, R. (2009). El corpus PUCV-2006 del español: identificación y definición 
de los géneros discursivos académicos y profesionales. Literatura y Lingüistica, 20: 75-101.

Parodi, G., Venegas, R., Ibañez, R. \& Gutiérrez, R. M. (2008). Géneros del discurso en el corpus PUCV2006 del español: Criterios, definiciones y ejemplos. In G. Parodi (Ed.), Géneros académicos y géneros profesionales: Accesos discursivos para saber y hacer (39-74). Valparaíso: Ediciones Universitarias de Valparaíso.

Piñuel, J. L. (2002). Epistemología, metodología y técnicas del análisis de contenido. Estudios de Sociolingüística, 3(1): $1-42$.

Russell, D. (1990). Writing Across the Curriculum in Historical perspective: Towards a social Interpretation. College English 52: 52-73

. (1991). Writing in the Academic Disciplines, 18701990: A curricular history. Carbondale, IL: Southern Illinois UP.

. (1997a). Writing and genre in higher education and workplaces: a review of studies that use culturalhistorical activity theory. Mind, Culture, and Activity, 4(4): 224-237.

. (1997b). Rethinking Genre in School and Society: An Activity Theory Analysis. Written Communication, 14: 504-540.

Silver, M (2006). Language across disciplines. Towards a critical reading of contemporary academic discourse. Boca Raton: Brown Walker Press.

Swales, J. (1990). Genre analysis: English in academic and research settings. Cambridge, UK: Cambridge University Press.

Tynjala, P., Mason, L. \& Lonka, K. (2001). Writing as a learning tool: Integrating theory and practice (Vol. 7). Springer Science \& Business Media.

Vásquez, A. (2005). ¿Alfabetización en la Universidad? [on-line]. Available in: http://www.unrc.edu.ar/unrc/ academica/pdf/cuadernillo01.pdf

Villalón, R. \& Mateos, M. (2009). Concepciones del alumnado de secundaria y universidad sobre la escritura académica. Infancia y aprendizaje, 32(2): 219-232.

Wenger, E. (1998). Communities of practice: Learning as a social system. Systems thinker, 9(5): 2-3.

Wolfe, J., Olson, B. \& Wilder, L. (2014). Knowing what we know about writing in the disciplines: A new approach to teaching for transfer in FYC. The WAC Journal, 25: 42-77. 